\title{
Leiomyosarcoma of the Gallbladder
}

\author{
Ali S. Sawan, MD, PhD and Sherine I. Salama, MSc \\ Department of Pathology, Faculty of Medicine, \\ King Abdulaziz University, Jeddah, Saudi Arabia \\ drassawan@yahoo.com
}

\begin{abstract}
Leiomyosarcoma of the gallbladder is a rare entity constituting about 1.4 per 1000 gallbladder malignancies. Few cases were reported in literatures most of which were in females in their sixth decade of life. This case represents an addition to this series. A case of a 50 years old, otherwise healthy, female patient, admitted with non-specific clinical presentation suggestive of cholecystitis was reported. The ultrasound impression was fatty hepatomegaly and cholecystitis with cholelithiasis. She was operated upon. A pedunculated polypoid mass $(1.5 \times 1.3 \mathrm{~cm})$ was incidentally discovered on the gross examination of the cholecystectomy specimen. Histopathological examination revealed spindle cell proliferation. The histological appearance of the mass examined was unquestionably malignant tumor of possible mesenchymal origin. Immunhistochemistry clearly demonstrated that the tumor on hand was a true sarcoma of smooth muscle origin (Positive for vimentin, smooth muscle actin and Desmin).
\end{abstract}

Keywords: Leiomyosarcoma, Gallbladder tumors, Malignancies of gallbladder.

\section{Introduction}

Primary leiomyosarcoma of the gallbladder is an uncommonly encountered tumor in the routine histopathology practice. These cases constitute about 1.4 per 1000 gallbladder malignancies ${ }^{[1]}$. According to Newmark et al. ${ }^{[2]}$, who reported the first case in 1879 , followed by Landsteiner in $1904^{[3]}$. Our search through the Medline for more recent literature revealed 19 reported cases of leiomyosarcoma. Therefore, our

Correspondence \& reprint request to:

Dr. Ali S. Sawan

P.O. Box 80215, Jeddah 21589, Saudi Arabia

Accepted for publication: 29 June 2010. Received: 29 March 2010. 
case will be the $20^{\text {th }}$ in this series ${ }^{[2,4-20]}$. In most reported cases, the presence of tumor was incidental finding being overshadowed by the clinical presentation of classic cholecystitis with or without cholelithiasis. Preoperative radiological examination may not detect the presence of significant lesion. Accurate diagnosis was only established after thorough histological and immunohistochemical evaluation.

\section{The Case}

The case report of a 50-years-old female patient, who was admitted to the surgical department with a provisional diagnosis of "chronic cholecystitis" was presented. A diagnosis was based on a vague history of right upper abdominal pain radiating to the back, nausea and vomiting. No other pertinent history was elicited, and there was no evidence of other pathological process elsewhere on clinical examination.

The complete blood profile and the liver function tests were within normal range. The urine examination revealed normal profile with absence of glucose, urobilinogen and bilirubin. Ultrasound of the abdomen revealed enlarged liver with diffuse bright homogenous texture. No focal lesions were identified. The gallbladder was average in size showing normal wall thickness and multiple stone. The final ultrasound impression was "fatty hepatomegaly and calcular gallbladder".

In the Histopathology Lab, a specimen was received in a 1 NBF container labeled with the patient name, hospital number and as "gallbladder". It was a previously opened gallbladder measuring $7.5 \times 2$ $\times 2 \mathrm{~cm}$ and the wall thickness was $0.4 \mathrm{~cm}$. The outer surface was dull, opaque and congested with focal areas of fibrous adhesions. The mucosa was velvety with green-brown tinge. There was a single pedunculated polypoid mass measuring $1.5 \times 1.3$ seen hanging from the mucosa and projecting into the lumen with an overlying necrotic surface. It was $3 \mathrm{~cm}$ away from the tip of the gallbladder. The mass was firm in consistency, tan-white in color with homogenous, solid rubbery cut surface without evidence of hemorrhage or necrosis.

Microscopic examination on the base of the polypoid lesion disclosed an area composed of an admixture of normal-appearing glands lined by tall columnar cells without evidence of cytological atypia, and surrounded by a spindle cell proliferation extending from the muscle layer of the gallbladder. The distal portion of the lesion was an 
exophytic, with more densely cellular neoplastic growth pushing the overlying sloughed and ulcerated mucosa ahead. The tumor was composed of pleomorphic spindle cells displayed into bundles, fascicles and sheets. The neoplastic cells have spindly to the oval blunt-ended large nuclei, abundant eosinophilic cytoplasm, clumped chromatin and inconspicuous nucleoli. Frequent and atypical forms of mitosis are appreciated. Scattered multinucleated tumor giant cell forms are also found (Fig. 1-4).

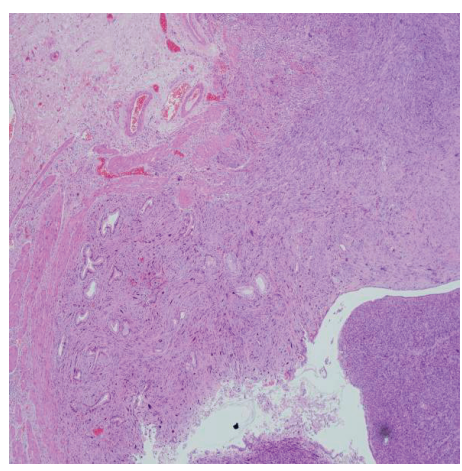

Fig. 1. H\&E, low power view at the base of the polypoid lesion revealing an area composed of an admixture of normal-appearing glands without evidence of cytological atypia, surrounded by a spindle cell proliferation extending from the muscle layer of the gallbladder.

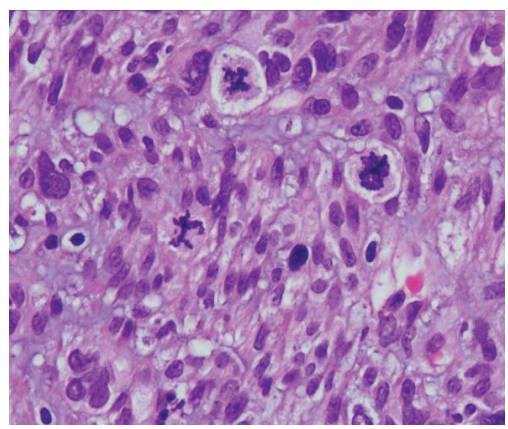

Fig. 3. H\&E, high power showing the high mitotic activity of the tumor cells with frequent abnormal forms.

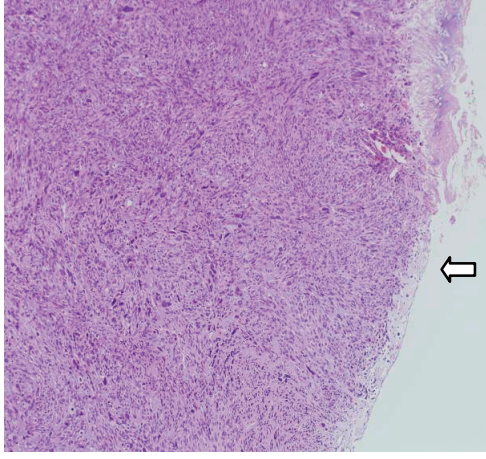

Fig. 2. H\&E of the head of the polypoid tumor revealing essentially spindle cell proliferation. The overlying mucosa is ulcerated.

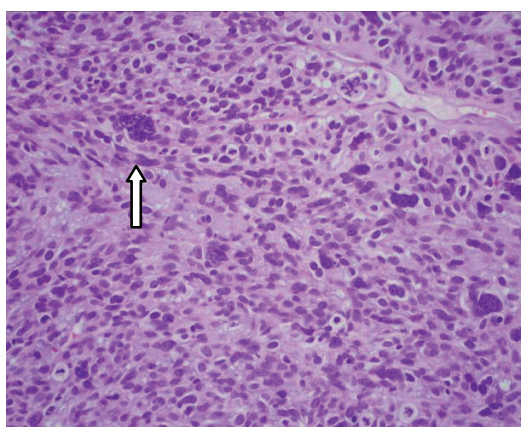

Fig. 4. H\&E, high power, tumor cells are spindled with high degree of atypia and bizarre nuclei. Scattered multinucleated tumor giant cell forms are also found (arrow head). 
Panel of immunohistochemical markers was performed on the formalin-fixed, paraffin embedded tissue blocks using the "avidin-biotinperoxidase method. The tumor cells showed positive immunoreactivity for "Vimentin, smooth muscle Actin and Desmin". There were negative immunoreactivity for the following markers; CK-Pan, CK7, CEA, CD117, CD34, chromogranin, synaptophysin, S100, and HMB45 (Fig. $5)$.

In the light of the morphological appearance and immunohistochemical results, the tumor was designated as "features consistent with sarcoma of the gallbladder with immunohistochemical profile favoring leiomyosarcoma".
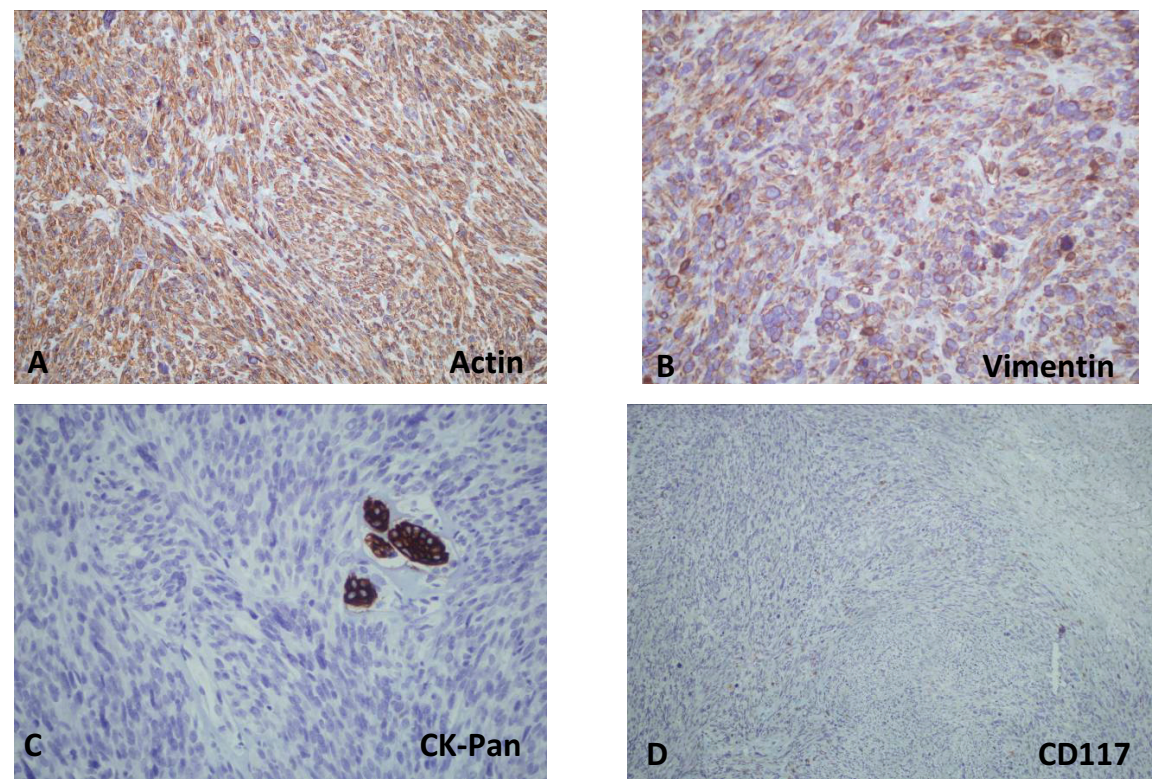

Fig. 5. IHC profile of tumor cells. Tumor cells are positive for Smooth muscle actin (A) and Vimentin (B), while negative for Pan Cytokeratin with positive internal control in the entrapped normal glands (C) and CD117 (D).

\section{Discussion}

Leiomyosarcoma is a malignant mesenchymal tumor composed of cells showing smooth muscle differentiation. This tumor usually occurs in middle-aged or older adults, and forms a significant percentage of retroperitoneal, vascular, extremity, and uterine sarcomas. However, their existence as a mesenchymal neoplasm of the gallbladder are a rare 
entity, and for the most part have been reviewed as an isolated case reported in the literature. Most of the reported cases were females in their six decade of life with vague clinical presentation suggestive of cholecystitis $^{[2,4]}$.

The historical argument upon the existence of this type of gallbladder sarcoma have been raised by Appleman and Coopermith in $1970^{[21]}$, who have suggested that among the reasons for erroneous diagnosis of sarcoma might be in part related to the tendency to consider any undifferentiated spindle-cell neoplasm as sarcoma. Also for the labile nature of neoplastic epithelium which may change in shape and pattern of growth rapidly. It is undeniable that the evaluation of spindle cell proliferation in the gallbladder is a challenge for the practicing pathologist when relied solely on histological appearance. However, the technological advances in radiological modalities, electron microscopy and the use of immunohistochemistry have eliminated most of these problems assisting the examining pathologist to differentiate between the most common types of gallbladder tumors.

Because of the rarity of leiomyosarcoma in the gallbladder, few authors have described its radiologic appearance ${ }^{[2]}$; it showed a dilated gallbladder with irregularly thickened wall and polypoid protrusion into the lumen. However, the polypoid appearance of the tumor might place it in a wider spectrum of differential diagnoses which includes true polypoid neoplasms, such as adenomas or adenocarcinomas, and nonneoplastic polyps, such as cholesterol polyps, inflammatory polyps, and adenomyoma-tous hyperplasia ${ }^{[22]}$. Based on ultrasound (US) appearance, the only significant discriminating feature between benign and malignant polypoid lesion was the size with a cut-off figure of $10 \mathrm{~mm}$. False positive and false negative results were referred to in the literature ${ }^{[23]}$. The case reported herein is an example of the limitation of US in some cases. The non specific clinical picture combined with gall stones lead to false preoperative interpretation as cholecystitis. In the study of Fotiadis et $a l .{ }^{[13]}$, the tumor was also incidental, missed on US while the true diagnosis was only made on histological examination.

Immunohistochemistry was the most helpful modality to establish the diagnosis. A platform of carefully selected immunohistochemical markers was our strategy in reaching an accurate diagnosis within a list of the most common mesenchymal tumors that tend to occur in this 
location. The differential diagnosis of this case essentially includes any spindle cell tumor of the gallbladder most importantly; leiomyosarcoma, fibrosarcoma, undifferentiated carcinoma with spindle cell morphology, carcinosarcoma, and the recently described stromal tumor of the gallbladder with a phenotype similar to that of gastrointestinal stromal tumors (GIST). The immunopositivity for smooth muscle actin helped to eliminate the fibrosarcoma and favor the smooth muscle origin. The undifferentiated carcinoma (spindle-cell or pseudosarcomatous type) as was described by Guo et al., ${ }^{[24]}$ was found to be positive for EMA, Keratins and CEA, in keeping with that, our case was negative for CKpan, CK7, and CEA. This pattern was against the described immunoprofile of the so-called carcinosarcoma entity in which the spindle cell component shows feature of epithelial differentiation by immunohistochemistry and $\mathrm{EM}^{[25]}$. A lesion worth mentioning in this context was the recently described tumor resembling GIST with both benign and malignant categories. This tumor was presumed to arise from the cells of Cajal ${ }^{[26]}$. As its gastrointestinal counterpart, it shows positivity for CD34 and CD117 (c-kit). Our case was negative for both markers. Also excluded was the rare possibility of melanoma with negativity for HMB45.

In this reported case, the sex, age, clinical picture and US findings were suggestive of cholecystitis, the gross appearance raised the possibility of many non-neoplastic and neoplastic possibilities. However, the morphology of the lesion examined was unquestionably malignant tumor of possible mesenchymal origin. Immunohistochemistry clearly demonstrated that the tumor in hand (only positive for vimentin, smooth muscle actin and desmin) was a true sarcoma of smooth muscle origin.

\section{References}

[1] Willen R, Willen H. Primary sarcoma of the gallbladder. A light and electronmicroscopical study. Virchows Arch A Pathol Anat Histol 1982; 396(1): 91-102.

[2] Newmark H, III, Kliewer K, Curtis A, DenBesten L, Enenstein W. Primary leiomyosarcoma of gallbladder seen on computed tomography and ultrasound. $A m \mathrm{~J}$ Gastroenterol 1986; 81(3): 202-204.

[3] Landsteinner K. Ubas das Sarkom der Gallenblas. 17: 163-165. 1904. Ref Type: Generic.

[4] Elkaoui H, Bouchentouf SM, Sall I, Baba H, Ait AA, Zentar A, Sair K, Ichou M, Sbiti Y. [Leiomyosarcoma of the gallbladder]. Gastroenterol Clin Biol 2008; 32(8-9): 789-791.

[5] Perez-Montiel D, Mucientes F, Spencer L, Klaassen R, Suster S. Polypoid leiomyosarcoma of the gallbladder: study of a case associated with adenomyomatous hyperplasia. Ann Diagn Pathol 2004; 8(6): 358-363. 
[6] Bernardos L, Trujillo A, Huete A, Colon A, Martinez D, Calleja J, Camacho A. [Primary leiomyosarcoma of the gallbladder]. Rev Esp Enferm Dig 2004; 96(4): 286-287.

[7] Danikas D, Theodorou SJ, Singh R, Camal DE. Leiomyosarcoma of the gallbladder: a case report. Am Surg 2001; 67(9): 873-874.

[8] Zeig DA, Memon MA, Kennedy DR, Woodward SA, Fitzgibbons RJ, Jr. Leiomyosarcoma of the gallbladder--a case report and review of the literature. Acta Oncol 1998; 37(2): 212-214.

[9] Ikuno N, Makiyama K, Yoshida N, Omagari K. [Leiomyosarcoma of the gallbladder]. Ryoikibetsu Shokogun Shirizu 1996; 9: 335-337.

[10] Tocchi A, Codacci-Pisanelli M, Costa G, Lepre L, Agostini N, Maggiolini F. [Leiomyosarcoma of the gallbladder: a clinical case]. G Chir 1993; 14(8): 443-445.

[11] Kumar S, Gupta A, Shrivastava UK, Bhargava SK. Leiomyosarcoma of gallbladder: a case report. Indian J Pathol Microbiol 1993; 36(1): 78-80.

[12] Munoz E, Navarro A, Forcada P, Marco V, Veloso E, Marco C. [Primary leiomyosarcoma of the gallbladder.] Rev Esp Enferm Dig 1992; 82(4): 243-244.

[13] Fotiadis C, Gugulakis A, Nakopoulou L, Sechas M. Primary leiomyosarcoma of the gallbladder. Case report and review of the literature. HPB Surg 1990; 2(3): 211-214.

[14] Yoshida N, Mori N, Ishino T, Murata I, Makiyama K, Hara K. [A case of leiomyosarcoma of the gallbladder]. Nippon Shokakibyo Gakkai Zasshi 1990; 87(3): 865871.

[15] Egorov VP. [Gigantic leiomyosarcoma of the gallbladder]. Arkh Patol 1989; 51(6): 68-70.

[16] Gutstein D, Cabra de LB, Garcia CM, Hernandez Aznar JF, Vara TC. [Primary leiomyosarcoma of the gallbladder]. Rev Esp Enferm Apar Dig 1988; 74(2): 158-160.

[17] Tarasov SS, Zhuk NN, Kulikova NG. [Leiomyosarcoma of the gallbladder]. Arkh Patol 1987; 49(6): 69-71.

[18] Heitzman J. [Malignant leiomyosarcoma of the gallbladder]. Patol Pol 1985; 36(2): 208213.

[19] Friedland HM. Leiomyosarcoma of the gallbladder. J Med Soc N J 1971; 68(3): 205-206.

[20] Gonzalomendoza M, Guilar JC. [Leiomyosarcoma Of The Gallbladder.]. Sem Med 1963; 123: 2095-2096.

[21] Appelman HD, Coopersmith N. Pleomorphic spindle-cell carcinoma of the gallbladder. Relation to sarcoma of the gallbladder. Cancer 1970; 25(3): 535-541.

[22] Christensen AH, Ishak KG. Benign tumors and pseudotumors of the gallbladder. Report of 180 cases. Arch Pathol 1970; 90(5): 423-432.

[23] Ito H, Hann LE, D'Angelica M, Allen P, Fong Y, Dematteo RP, Klimstra DS, Blumgart LH, Jarnagin WR. Polypoid lesions of the gallbladder: diagnosis and follow up. J Am Coll Surg 2009; 208(4): 570-575.

[24] Guo KJ, Yamaguchi K, Enjoji M. Undifferentiated carcinoma of the gallbladder. A clinicopathologic, histochemical, and immunohistochemical study of 21 patients with a poor prognosis. Cancer 1988; 61: 1872-1879.

[25] Suster S, Huszar M, Herczeg E, Bubis JJ. Adenosquamous carcinoma of the gallbladder with spindle cell features. A light microscopic and immunocytochemical study of a case. Histopathology 1987; 11(2): 209-214.

[26] Mendoza-Marin M, Hoang MP, bores-Saavedra J. Malignant stromal tumor of the gallbladder with interstitial cells of Cajal phenotype. Arch Pathol Lab Med 2002; 126(4): 481-483. 


\section{ساركوما عضلية ملساء بالحويصلة المر ارية: تقرير حالة

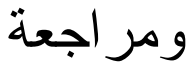

\section{علي صادق صوان، وشيرين إبراهيم سلامة}

قسم علم الأمراض ، كلية الطب، جامعة الملك عبدالعزيز

جدة - المدلكة العربية السعودية

المستخلص. الساركوما العضلية الملساء بالدويصلة المرارية هو

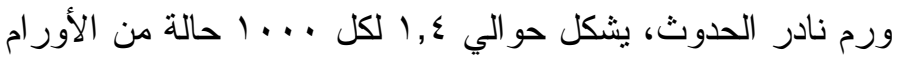
الخبيثة للحويصلة المرارية. ولم يتم تشخيص إلا حالات قليلة التيلة ومعظمها من النساء في العقد السادس من العمر . وحالتنا الحالية تمتل إضافة إلى هذه السلسلة. فندن نقدم تقرير حالة أنثى تبلغ من

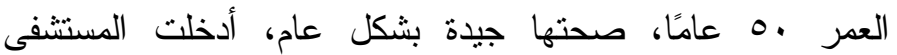
بأعراض إكلينيكية غير محددة توحي بالتهاب في الحويصلة المرارية. كان انطباع الموجات فوق الصوتية هو تدهن في الكبد،

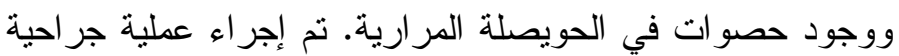
لها، وأثناء الفحص العيني الإجمالي الجهري للعينة الجراحية تم

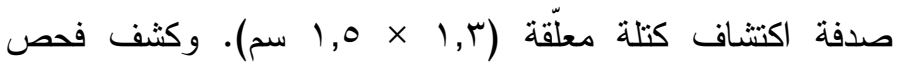

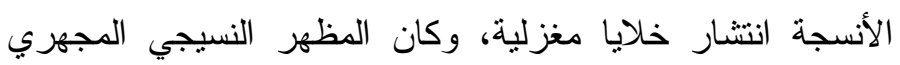

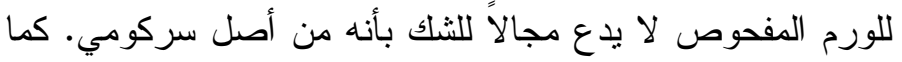
أوضح فحص الأنسجة بالصبغة - الكيمياء المناعية - أن أصل هذا لأل الصاء الورم السركومي هو العضلات الملساء (نتيجة إيجابية للقايمنتين، الدسمين و أكتين العضلات الملساء). 